\title{
表情の瞬間的変化の認知 ${ }^{1)}$
}

\author{
織 田 朝 美（関西大学大学院総合情報学研究科） \\ 向田茂 (ATR 人間情報科学研究所) \\ 加藤隆 (関西大学総合情報学部)
}

Perceiving a momentary change in facial expression

\author{
Asami ORITA (Graduate School of Informatics, Kansai University) \\ Shigeru MUKAIDA (ATR Human Information Science Laboratories) \\ Takashi KATO (Faculty of Informatics, Kansai University)
}

This study investigates perception for momentary changes in facial expressions using motion stimuli of faces. Within each set of motion stimuli, a facial expression showing either anger, sadness, or happiness was inserted momentarily, presented for either $130 \mathrm{~ms}, 220 \mathrm{~ms}, 330 \mathrm{~ms}$, or $530 \mathrm{~ms}$. One group of participants was asked to rate the level of pleasantness evoked by the complete set of stimuli, while a second group was asked to categorize the inserted facial expression as being happy, sad, angry, or neutral. Pleasantness ratings were higher when the inserted expression was happy compared to sad or angry. Categorization of the inserted facial expressions was quite accurate for angry and happy, but correct categorizations of angry were lower in the $130 \mathrm{~ms}$ condition. Although the pattern of results indicate that the participants were sensitive to momentary changes in facial expressions at durations of at least $200 \mathrm{~ms}$, further research is needed to investigate why the perception of momentary changes varies for happy, angry and sad.

Key words : facial expressions, categorization, pleasantness, emotion

本研究では，瞬間的に変化する表情を人がどの程度正確に認知できるか，また瞬間的な表情変化に対して どのような情動的反応を示すかについて検証した。実験刺激には，途中で瞬間的に表情が変化する動画を用 い，動画全般から受ける好意度の評定と，瞬間的に変化する挿入表情の分類判断を行わせた．途中の表情変 化の呈示時間を 530 ミリ秒，330 ミリ秒，200ミリ秒，130 ミリ秒へと減少させたが，挿入表情が笑顔の 場合に，怒りや悲しみの場合に比べて高い好意度評定值を示し，瞬間的な表情変化への情動的反応が認めら れた。一方，挿入表情が笑顔と怒りの場合には，200ミリ秒までは高い分類成績を示したが，変化速度が 130 ミリ秒に減少すると，怒りの分類成績が低下した。表情変化の時間が 200 ミリ秒程度あれば，表情の 変化を認知できるといえるが，表情認知の容易性における 3 表情の差異が何に起因するかについてさらな る検討が必要である。

キーワード：顔の表情，分類，情動，感情

日常生活において私たちが最む多く接する視覚刺激の 1 つが人の顔である。私たちは顔について, 形状や肌の 特徵に基づく性別や年齢の推測 (e.g., Shepherd, 1989), 顔の既知性に基づく人物の同定 (e.g., Bruce \& Young, 1986)，表情認知に基づく情動状態の推測 (e.g., Ekman, 1993), さらには人物の性格 (Dion, 1972) や職業 (Klatzky，1986)についての印象判断など，様々な認知的・ 感情的処理を行っている.

人と人との対面対話においてはとりわけ表情が重要な

1) 本研究の一部は 2003 年度 -2007 年度文部科学省私立 大学学術研究高度化推進事業の研究助成 (第一著者並 びに第三著者）及び情報通信研究機構の研究委託（第 二著者）により行った.
役割を果たすことになる，表情から相手の情動状態を推 測するだけではなく, 特定の表情を表出することによっ て自らの情動状態を相手に伝えようとする。こうした表 情のカテゴリ分類については多くの提案がなされていて (e.g., Charlesworth \& Kreutzer, 1973; Ekman \& Friesen, 1978; Russell \& Bullock, 1985), たとえば Ekman \& Friesen (1978) は“幸福”，“驚き”，“恐れ”, “悲しみ”，“怒り”，“嫌悪（または軽蕆），“興味”の表 情カテゴリがきわめて独立的で安定的であると主張して いる.

また, 表情のカテゴリを多次元の表情空間によって表 す試み屯多くの研究者によってなされており (cf. Smith \& Ellsworth, 1985), これらの分析において“快一不 
快”の次元が必ず抽出されていることから, 表情の分類 には“快一不快”の判断が重要な働きをすることが示唆 される.さらに，“覚醒水準”や“注意的活動性”とい う次元も多くの分析に拈いて抽出されている. たとえば， 蒲池・行場 (1998) は, 表情の強度についての評定值を 用いて主成分分析を行い, “笑顔”, “悲しみ”, “驚き”, “怒り”, “嫌悪”, “中性”の 6 つの表情力テゴリが“快 一不快”之“覚醒水準” の 2 つの次元からなる表情空 間によって表されることを示している.

しかしながら, 表情による情動状態の伝達がどの程度 普遍的かつ正確に行われるあのなのか, あるいは顔のど のような視覚情報に基づいて行われるあのなのかについ ては必ずしも一致した見解は得られていない.たとえば, 文化に依存しない基本的かつ普遍的な表情カテゴリが存 在する (e.g., Ekman, 1993; Ekman, 1994) とする主張 がある一方で, 表情認知がきわめて文脈依存的であるこ とを示す実験結果 (e.g., 加藤・赤松, 1998; Russell \& Fehr, 1987） が数多く示されており，表情カテゴリの 普遍性に疑問を呈する研究者 (e.g., Russell, 1997) あい る。また，表情認知が顔の特定のパーツ（部位）に含ま れる視覚情報に依存するあのなのか（e.g., 加藤・中口・ 木幡・丸谷, 1998), あるいはパーツの相互作用に影響 を受けるあのなのか (McKelvie, 1973), さらには，特 定のパーッではなく全体的に布置された視覚情報に基づ くものなのかという疑問がある.これは，表情を顔の全 体的特徴として捉えるべきであるとした場合に, どのよ うな体系で表情を記述すればよいのかという問題にあつ ながる（桐田, 1993）.

こうした研究は表情の静止画を用いて行われてきたが, 近年は動画を用いた研究も進められている. 表情が表出 される際の顔の動きや時間経過の情報は静止画では失わ れてしまうが, 実験刺激として動画を用いることで, こ うした要因についての分析や検証が可能になると期待で きる.たとえば, Kamachi, Bruce, Mukaida, Gyoba, Yoshikawa, \& Akamatsu (2001) は表情の表出速度と 表情認知の関係について動画刺激を用いた実験的検証を 行っている. 表情の動画は, 無表情の静止画と笑顔など の表情の静止画を用いて，2 枚の画像の混合割合を徐々 に変化させた合成画像を連続表示することで実現されて いる. 実験では, 表情ごとに 3 種類の速度で表情動画 像が提示され, 表情の自由分類と表情の強度に対する評 定が比較された. その結果, たとえば, 笑顔は比較的速 く表示された場合に, 悲しみは比較的ゆっくりと表示さ れた場合に的確に認知されやすいことや, 怒りの表情は ゆっくりと表示された場合に悲しみと混同されやすいこ となど，表示速度によって表情の認知が影響されること が示された。

本研究は, 単一の動的表情の認知ではなく, ある表情
から別の表情へと瞬間的に变化し, またもとの表情に戻 るという瞬間的な表情变化の認知について検討を加えた あのである. 情動状態の変化と顔の表情の変化はしばし ば意図に反して連動してしまう。たとえば，自分が不快 な情動状態であることを相手に察知されたくないときに は表情の表出を抑制しようとするだろう。しかしながら， その意図に反して反射的に表情が一瞬变化してしまうこ とあある. そうした場合に，相手はその一瞬の表情の変 化に容易に気づくのだろうか. 相手が一瞬の表情変化に まったく気づかないこともあるだろうし, 変化した表情 の認知はできなくても不快な情動状態にあることを漠然 と察知するかむしれない. すなわち, 表情分類という認 知的な課題の遂行と表情変化への情動的反応の間に乘離 が見られるか屯しれないということである。そこで本研 究では, 瞬間的な表情変化の知覚が変化前後の表情に よって影響を受けるかどうかも含めて, 動画全体を見て 行う好意度評定という情動的な課題と挿入された瞬間的 な表情の分類という認知的な課題とでは瞬間的な表情变 化に対する処理が異なるかについて検証することにした.

\section{実験 1}

\section{方法}

被験者 入門レベルの認知科学を履修中の大学生計 72 名が下記に示す好意度評定課題と表情分類課題に 36 名ずつ無作為に配置された.

実験素材と実験デザイン 本実験で用いた表情は，笑 顔, 悲しみ, 怒り, 真顔 (無表情) の 4 種類であった. 実験刺激として用いる動画を作成するために, ATR が 所有する男女各 61 名分の表情画像データベースの中か ら, 表情表出度の評定值（小川・尾田，1998）に基づ いて，笑顔，悲しみ，怒りの表情がいずれも高い表出度 をあつとされた顔を男女それぞれについて 9 名選出し た。これらの顔はすべて， 7 段階評定で，笑顔が 4.2 以 上, 悲しみが 4.0 以上, 怒りが 4.0 以上の評定值を得て いるあのであった.

次に，動画作成に用いる静止画を作成するために，男 女各 9 名の表情顔画像について, ATR 顔画像合成シス テムFUTON（向田・蒲池・尾田・加藤・吉川・赤 松・千原，2002）によるモーフィング合成を行った. 動画は, 怒り, 悲しみ, 笑顔の各表情の静止画と無表情 の静止画を用いて, 表情画像と無表情画像の混合割合を 徐々に変えて複数のモーフィング合成画像を作成し，そ れらを連続表示することで実現した.モーフィング画像 の連続表示には ACCOM 社製 WSD/2Xtreme を用い, 30 フレーム/秒で動画表示した.この動画像をデジタ ルビデオカセットに録画して, 本実験の呈示刺激として 用いた. これらの動画は基本的に表情が途中で変化する むので，たとえば，怒りの表情で始まり，怒りの表情で 
(a) 挿入表情の表示速度: 速い

\section{挿入表情}

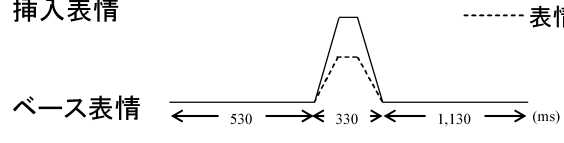

(b) 挿入表情の表示速度: 遅い

\section{挿入表情}

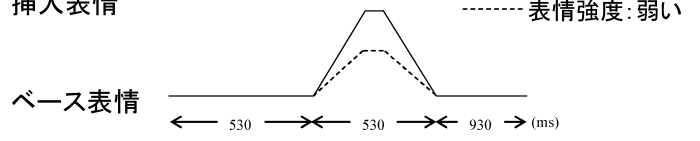

Figure 1. Schematic illustrations of motion stimuli.

終わるのだが，途中で悲しみの表情が瞬間的に表示され るというあのであった.

呈示刺激は，まず，笑顔，怒り，悲しみのいずれかの 表情が呈示された後, 笑顔, 怒り, 悲しみのいずれかの 表情が瞬間的に挿入され，再び元の表情へと戻るあので あった．たとえば，怒りの表情が呈示され，瞬間的に笑 顔の表情へと変化し, 再び, 怒りの表情へと戻るという むのである (Figure 1). 本稿では，この途中で瞬間的に 挿入される表情を「挿入表情」と呼び，挿入表情の前後 に呈示される表情を「ベース表情」と呼ぶことにする.

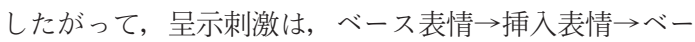
ス表情の順に呈示される 3 つのパートから構成されて いることになる.

動画像の構成要素である静止画像についてであるが, ベース表情や挿入表情に用いられる画像には, デー夕 ベースから抽出した各表情のオリジナル画像そのもので はなく, 各表情のオリジナル画像と真顔とを $75 \%$ : 25\%の割合でモーフィングしたものを用いた。この画 像が本実験の動画刺激における各表情の基準となること から，これを「基準混合画像」と呼ぶことにする.

ベース表情の呈示には, 基準モーフィング画像の前後 4\%ずつの範囲で 2\%刻みに真顔と合成した画像（表情 画像の混合割合 69\%～81\%: 7 枚）を作成し，それらを 連続表示することで, 表情が一定時間なめらかな動きを 示すようにした.

ベース表情から挿入表情への変化は, ベース表情の基 準混合画像と挿入表情の基準混合画像とをモーフィング し，ベース表情から挿入表情へ連続的に变化するように した.

ベース表情と挿入表情の表情が同じ場合は, ベース表 情の画像には基準混合画像を, 挿入表情の画像には, データベースから選出したオリジナル画像を用い, ベー ス表情から挿入表情への連続変化となるようモーフィン グを行った。
挿入表情の強度については, 強度が強い条件と, 弱い 条件との 2 通りを用いた。 強度が強い条件では, ベー ス表情から挿入表情へとそのまま連続変化するようモー フィングを行ったが, 強度が弱い条件では, ベース表情 から挿入表情の $50 \%$ の強度へと連続変化するようモー フィングした。 すなわち, 強度の弱い条件で呈示される 挿入表情はベース表情 $50 \%$ と挿入表情 $50 \%$ の混合割 合となった。

挿入表情については，さらに，表情変化の速度につい て速い条件と遅い条件の 2 通りを設定した．表情の変 化速度は，速い条件では 10 枚の静止画を連続表示する ことで約 330 ミリ秒とし, 遅い条件では 16 枚の静止画 を連続表示することで約 530 ミリ秒となるようにした。 動画全体の呈示時間を一定にするために，動画の表示開 始から表情变化までの時間については表情变化の速い条 件と遅い条件ともに約 530 ミリ秒としたが，表情変化 の終了から動画の表示終了までの時間は速い条件では約 1,130 ミリ秒とし, 遅い条件では約 930 ミリ秒とした. したがって，実験刺激の呈示時間は両条件ともに約 2,000 ミリ秒に統一されていた.

上述の通り, ベース表情と挿入表情の組み合わせにつ いて計 9 通り, 挿入表情の表出度について“強い・弱 い”の 2 通り, さらに挿入表情の変化速度について “速い・遅い”の 2 通りの条件があった。 これらすべて の条件をかけ合わせた計 36 通りの動画刺激を男女各 9 名それぞれの顔に対して作成した。そして，変化速度の 条件別に, 男女各 9 名の顔の動画刺激をデジタルビデ オテープに編集した。このとき, 同じ人物の顔は 1 回 しか呈示されないように，同じ条件（ベース表情と挿入 表情の組み合わせ / 表情の強弱) の動画刺激む 1 回し か呈示されないようにするという制約を設けた。この制 約を満たし, かつ, 男女各 9 名の動画刺激をすべて均 等に用いるために，18 個の動画刺激がランダムな順番 に編集されたデジタルビデオカセットを, 变化速度の速 い条件と遅い条件に対して各々 18 本（計 36 本）を作 成し，呈示刺激として用いた。

実験手続き 実験では, 変化速度の条件ごとに, 18 個の表情の動画が連続して呈示された. 各々の動画は, 動画刺激の順番を示す数字, 動画刺激の呈示が直後に開 始されることを知らせる注視記号 $(+)$ に続いて呈示さ れた (Figure 2 参照). デジタルビデオテープは, ポー タブルデジタルビデオ (Sony Handycam DCR-PC10) で再生され, 14 インチカラーテレビ (Sony KV-14 DA 1)に表示された.

好意度評定課題を行う被験者は, テレビ画面に表示さ れる表情がどの程度の好意度を表すむのかについて 7 段階で評定するよう求められた。被験者は, 表情が被験 者に向けて表出されたものではなく, 別の人物に向けら 
れたものであるとして評定するよう求められた，具体的 には，“あなたは友人と話をしています。すると，ドア から人が入ってきました，その人を見たときの友人の表 情が今から画面に出てくるものです，友人はドアから 入ってきた人を好意的に思っているか，思っていないか を 7 段階で評定してください, という趣旨の教示が与 えられた. ただし, 教示では途中で表情が変化すること については何屯触れなかった。

表情分類課題を行う被験者は, 動画の途中に挿入され る表情が, 笑顔, 悲しみ, 怒り, 無表情のいずれである かを判断するよう求められた，好意度評定課題と同様の 状況を想定するように求める教示に加えて, “友人の表 情は, 最初の表情からある表情へ变化し，また元の表情 に戻ります。途中で変化した表情を笑顔・悲しみ・怒 り・無表情の 4 つから判断してください.”との教示が 与えられた。

好意度評定課題と表情分類課題のいずれにおいても， 各被験者は变化速度の速い条件の動画と変化速度の遅い 条件の動画を呈示された. 呈示条件の順序効果を相殺す るために, 変化速度の速い条件の動画を先に呈示される 被験者グループと, 変化速度の遅い条件の動画を先に呈 示される被験者グループの 2 群を設け，それぞれ 18 人 ずつを無作為に配置した。

\section{結果と考察}

好意度評定の結果（Figure 3 参照：挿入表情の強度 が強い場合の結果のみを表示）に対して, ベースの表情, 途中で变化する表情, 挿入表情の強弱, 挿入表情の変化 速度の 4 つを要因とする 4 元配置の分散分析を行った. 挿入表情の変化速度については, 主効果抢よびその他の
要因との交互作用において有意差が認められなかった. また，挿入表情の強弱については，主効果は認められな かったが，ベース表情执よび挿入表情との交互作用が有 意であった，そこで，変化速度の 2 条件をまとめて 2 つの評定值の平均值を求め, 挿入表情の強い条件之弱い 条件に分けて，3 (ベース表情) $\times 3$ (挿入表情) の 2 元 配置の分散分析を行った。

挿入表情の強度が強い場合は, ベース表情の主効果 $(F(2,280)=56.81, p<.0001)$ と挿入表情の主効果 $(F(2$, $280)=59.48, p<.0001)$ がそれぞれ有意であったが, 2 つの要因の交互作用は有意ではなかった $(F<1)$. 挿入 表情の主効果について Tukey-Kramer 法を用いた多重 比較による下位検定を行ったところ，3つの挿入表情の 間にそれぞれ有意差が認められた。

挿入表情の強度が弱い場合は，ベース表情の主効果 $(F(2,280)=127.50, p<.0001)$, 挿入表情の主効果 $(F(2,280)=24.32, \quad p<.0001)$, および交互作用 $(F(4$, $280)=2.92, p<.05)$ が有意であった. 挿入表情につい て単純主効果分析を行ったところ, すべてのベース表情 に対して挿入表情に有意差が見られた. TukeyKramer 法による多重比較を行ったところ， ベース表情 が怒りの場合, 怒りの挿入表情に対して悲しみと笑顔の 挿入表情よりあ好意度が低いと評定されていたが，ベー ス表情が悲しみと笑顔の場合には，笑顔の挿入表情が他 の 2 つの挿入表情よりも好意度が有意に高いと評定さ れていたことがわかった。 つまり, 悲しみの挿入表情の 効果がベース表情によって異なることが交互作用の原因 であった。

次に, 挿入表情の分類判断における正答率（Figure

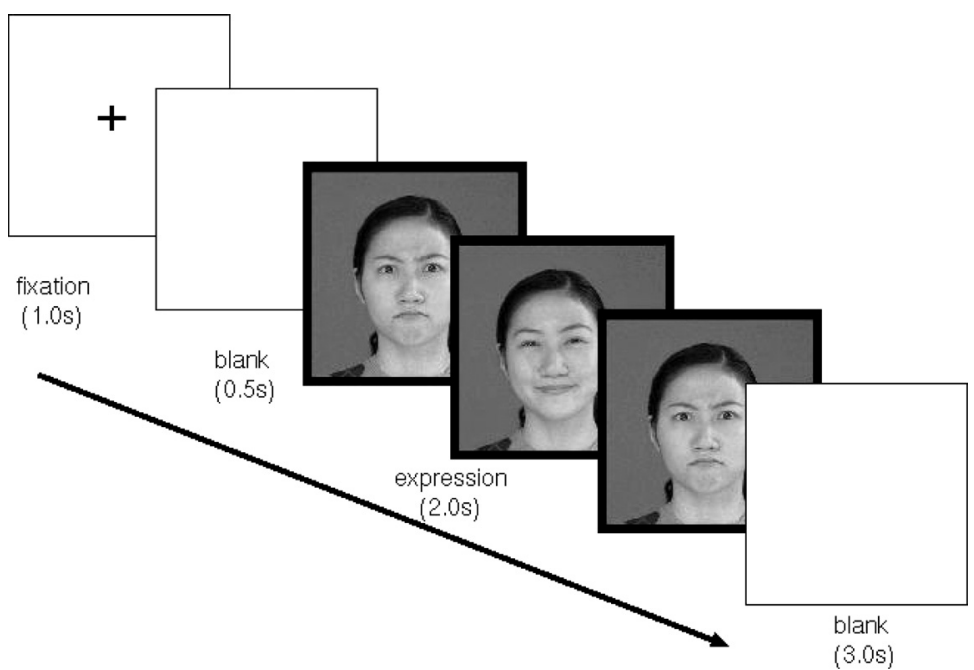

Figure 2. Stimulus presentation order for each video clip. 


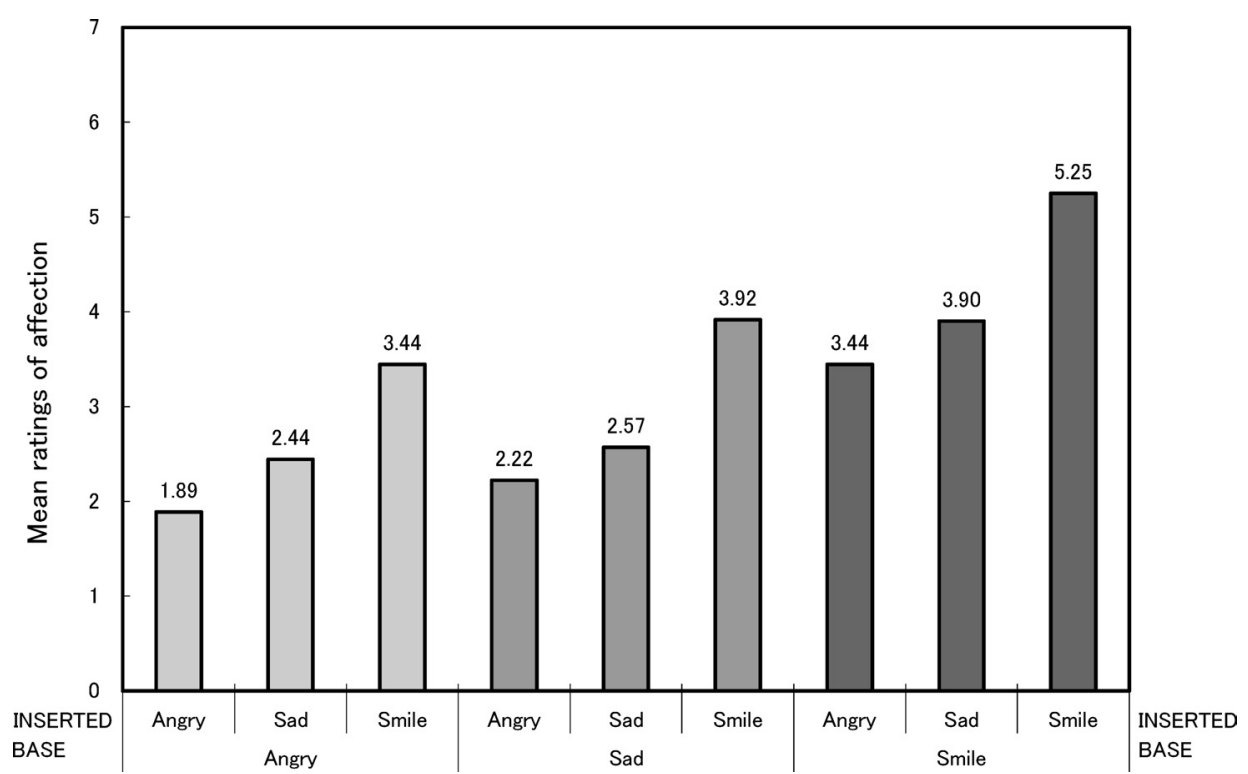

Figure 3. Mean ratings of affection as a function of base and inserted facial expressions for the Strong-Expression condition in Experiment 1.

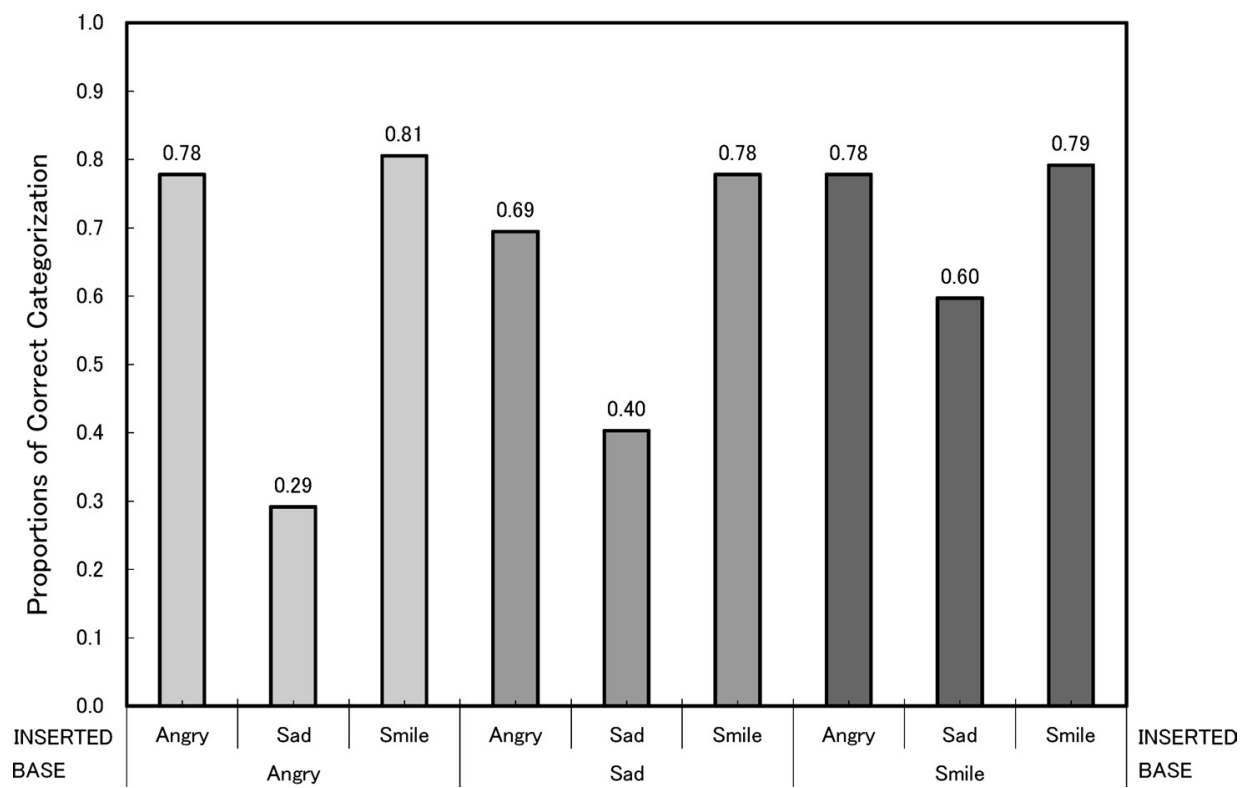

Figure 4. Proportions of correct categorization of inserted facial expressions as a function of base expressions for the Strong-Expression condition in Experiment 1.

4 参照：挿入表情の強度が強い場合の結果のみを表示） について，好意度評定と同様に，ベースの表情，途中で 変化する表情, 挿入表情の強弱, 挿入表情の変化速度の 4 つを要因とする 4 元配置の分散分析を行ったところ, 挿入表情の変化速度については主効果㧍よびその他の要
因との交互作用に扔いて有意差が認められなかった。ま た, 挿入表情の強弱については, 主効果が有意であり, ベース表情㧍よび挿入表情との交互作用が有意であった。 そこで，変化速度の 2 条件をまとめて正答率を求め, 挿入表情の強い条件之弱い条件に分けて，3（ベース表 


\section{認知心理学研究 第 3 巻第 1 号}

Table 1

Frequency table for categorization of inserted facial expressions for the Strong-Expression condition in Experiment 1.

\begin{tabular}{|c|c|c|c|c|c|c|}
\hline Base & Inserted & Total & Angry & Sad & Smile & Neutral \\
\hline Angry & Angry & 72 & 56 & 5 & 1 & 10 \\
\hline Angry & Sad & 72 & 22 & 21 & 7 & 22 \\
\hline Angry & Smile & 72 & 12 & 1 & 58 & 1 \\
\hline Sad & Angry & 72 & 50 & 10 & 1 & 11 \\
\hline Sad & Sad & 72 & 12 & 29 & 1 & 30 \\
\hline Sad & Smile & 72 & 6 & 9 & 56 & 1 \\
\hline Smile & Angry & 72 & 56 & 4 & 9 & 3 \\
\hline Smile & Sad & 72 & 6 & 43 & 17 & 6 \\
\hline Smile & Smile & 72 & 2 & 1 & 57 & 12 \\
\hline
\end{tabular}

情） $\times 3$ (挿入表情）の 2 元配置の分散分析を行った.

挿入表情の強度が強い場合は, ベース表情の主効果 $(F(2,280)=3.16, p<.05)$ ，挿入表情の主効果 $(F(2$, $280)=39.20, p<.0001)$, および交互作用 $(F(4,280)=$ $2.84, p<.05)$ が有意であった. 挿入表情の単純主効果 分析を行ったところ，すべてのべース表情において挿入 表情に有意差が見られた. その後の Tukey-Kramer 法 による多重比較では, ベース表情が怒りと悲しみの場合 には，悲しみの挿入表情に対する分類成績が怒りと笑顔 の挿入表情に対する分類成績よりも有意に劣るという結 果が現れたが，ベース表情が笑顔の場合には，3つの挿 入表情に有意差は認められなかった。すなわち，悲しみ の挿入表情に対する分類成績がベース表情によって異な ることが交互作用の原因であった.

挿入表情の強度が弱い場合は, ベース表情の主効果は 有意ではなかったが，挿入表情の主効果 $(F(2,280)=$ $17.67, p<.0001)$ ， および交互作用 $(F(4,280)=5.10$, $p<.001)$ が有意であった. 挿入表情の単純主効果分析 を行ったところ，怒りと笑顔のベース表情において挿入 表情に有意差が見られた。 Tukey-Kramer 法による多 重比較では, ベース表情が怒りの場合には, 悲しみの挿 入表情に対する分類成績が怒りと笑顔の挿入表情に対す る分類成績よりも劣るという結果が現れたが， ベース表 情が笑顔の場合には, 悲しみの挿入表情に対する分類成 績と怒りの挿入表情に対する分類成績には有意差は認め られなかった。 やはり, 悲しみの挿入表情に対する分類 成績がベース表情によって異なることが交互作用の原因 であったといえる.

実験 1 の結果において, 好意度評定課題と表情分類 課題のいずれにおいても挿入表情の効果が示された。す なわち，挿入表情の前後に現れるベース表情がまったく 同じであっても, 挿入される挿入表情の違いによって好 意度評定および表情分類の成績が異なることが示された。 ベース表情の効果とは別に, 挿入表情が怒りや悲しみと
いった不快情動を表す場合には表情全体の好意度が低く 評定され，挿入表情が快情動を表す笑顔の場合には好意 度が高いと評定されたことから，330ミリ秒－530ミリ 秒という瞬間的な表情の変化であっても, 好意度という 情動的判断に影響を及ぼすことが示されたといえる.ま た, 覚醒度が高いとされる怒りや笑顔の場合は, 前後に 異なる表情が表示されても，表情の分類判断の成績もよ く, 530 ミリ秒や 330 ミリ秒という短い呈示時間で あって屯表情の認知が的確に行われていることを示して いるといえる.

挿入表情が悲しみの場合，表情分類の正答率が全体的 に低く，特にベースの表情が怒りの場合に著しく低い值 を示した. Kamachi et al. (2001) あ悲しみの表情は表 出速度が速いと正しく認知されないという結果を示して いて, 彼女らの実験における表出速度と自由記述分類の 成績を見る限り, 実験 1 における变化速度は悲しみの 表情にとっては十分に速いものであることがうかがえる. 反応混同表 (Table 1 参照) を見てみると, 悲しみは無 表情や怒りに分類されることが多く, ベース表情の条件 によっては, チャンスレベル程度の分類成績しか示して いない。このことは, 悲しみが覚醒度の低い表情である ために, 怒りや笑顔のような覚醒度の高い表情が前後に くると, そうしたベースの表情に覆い隠されたり, 対照 的に中性的な無表情に見えたりするためではないかとむ 考えられる.さらに，怒りがベースの表情である場合に 悲しみが特に認知されにくいのは，同じ不快情動であり， かつ, 怒りよりあ覚醒度が低いために, 判断が困難に なっている可能性も考えられる.

\section{実験 2}

実験 1 の結果から，530ミリ秒や 330 ミリ秒といっ たきわめて短い呈示時間の表情变化でも, 人はその表情 のカテゴリを的確に認知し, 表情の情動性と整合性のあ る好意度を感じとることができるといえる. 実験 2 で 


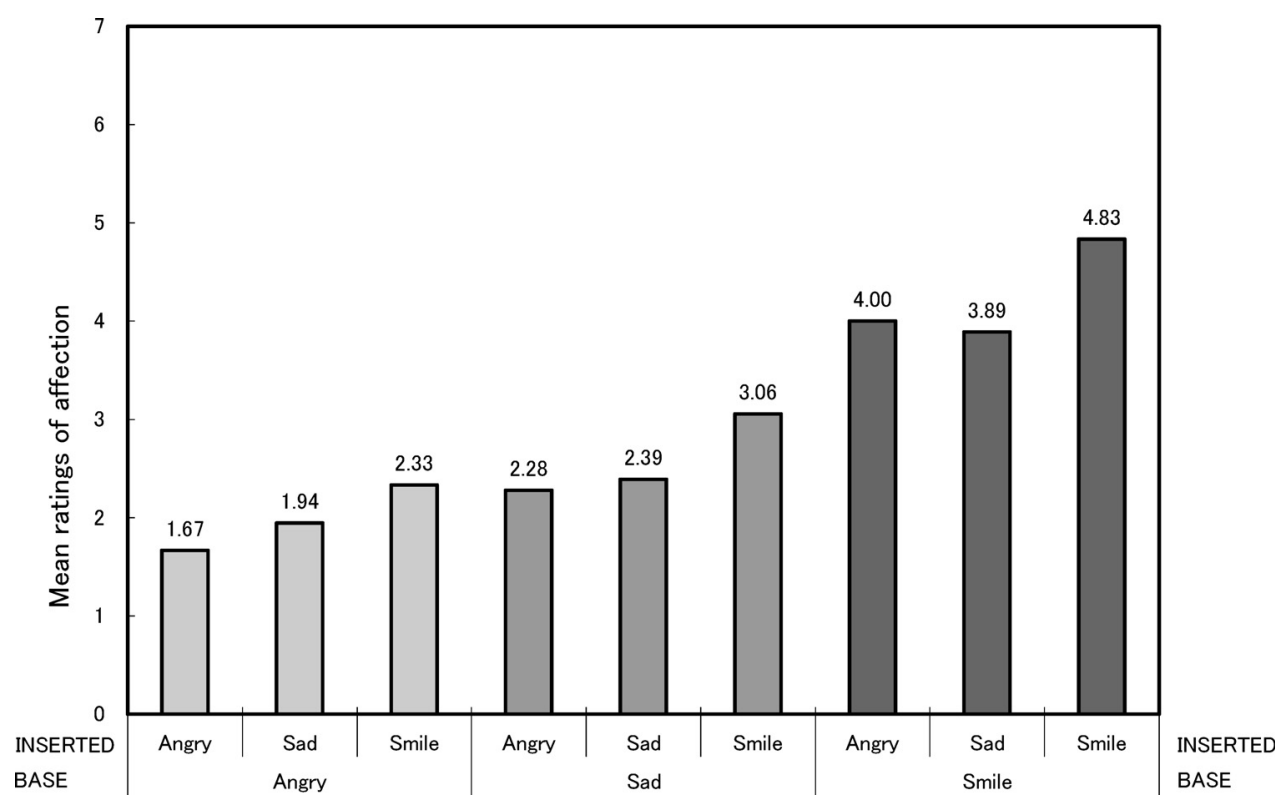

Figure 5. Mean ratings of affection as a function of base and inserted facial expressions for the 200 msec condition in Experiment 2.

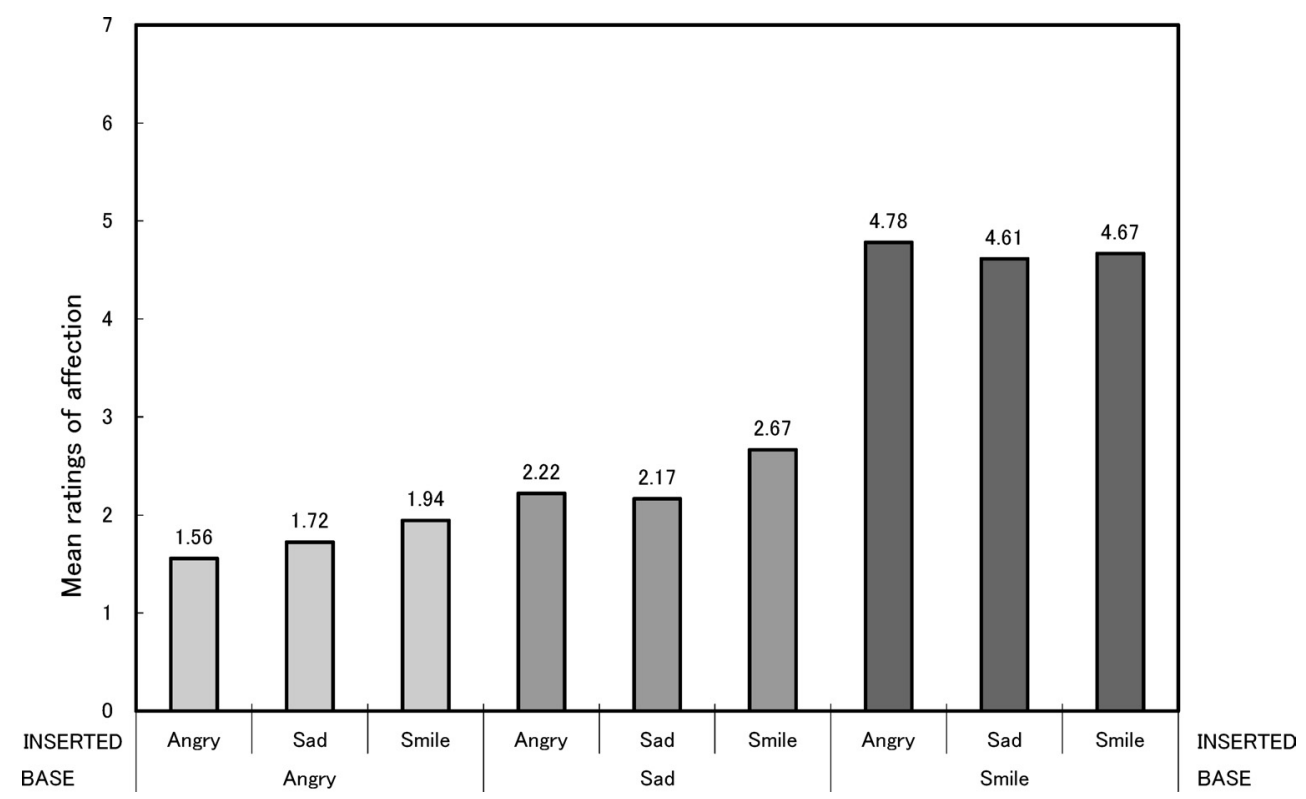

Figure 6. Mean ratings of affection as a function of base and inserted facial expressions for the 130 msec condition in Experiment 2.

は，表情の変化時間をさらに短くして，表情の好意度評 定之分類判断における的確さについて検証を重㸚ること にした。

\section{方法}

被験者 入門レベルの認知科学を履修中の大学生計 54 名が実験に参加した。好意度評定課題には 18 名が, 表情分類課題には 36 名が無作為に配置された。なお， 
いずれの被験者む実験 1 に参加していない者であった.

実験素材と実験デザイン 実験素材の作成は下記の点 を除いて実験 1 と同じであった，実験 2 では，挿入表 情の強弱については実験要因に含まないこととし, 実験 1 に㧍ける挿入表情の強度の強い条件のみを用いた。挿 入表情の変化速度については, 速い条件が約 130 ミリ 秒 (4 枚の静止画), 遅い条件が 200 ミリ秒（6 枚の静 止画）と，いずれも実験 1 の速い条件よりもさらに速 い変化速度での呈示とした，その他の点については実験 1 と同様に動画刺激の作成を行った.

挿入表情の強弱を実験要因加ら除いて強度の強い条件 のみを用いたことから, 実験条件は 3 (ベース表情) $\times 3$ (挿入表情) $\times 2$ (変化速度) の計 18 通りとなった. 呈 示用デジタルビデオカセットの編集にあたっては, 男女 各 9 名の顔は 1 回しか呈示されないように, 同じ条件 (ベース表情と挿入表情の組み合わせ/挿入表情の変化 速度）の動画刺激む 1 回しか呈示されないようにし, かつ男女各 9 名の動画刺激をすべて均等に用いるため に，18 個の動画刺激がランダムな順番に編集されたデ ジタルビデオカセットを計 18 本作成した。

実験手続き 各被験者は好意度評定か表情分類のいず れかの課題を 1 本のデジタルビデオテープに収められ た 18 個の動画刺激に対して行った. その他の手続きは 実験 1 とまったく同じであった。

\section{結果と考察}

好意度の評定結果 (Figure 5 および Figure 6 参照) に対して, ベースの表情, 途中で変化する表情, 挿入表 情の変化速度の 3 つを要因とした 3 元配置の分散分析 を行ったところ, ベース表情の主効果 $(F(2,289)=$ $156.43, p<0.0001)$, 挿入表情の主効果 $(F(2,289)=$ $6.54, p<0.005)$, およびベース表情と変化速度の交互作 用 $(F(2,289)=3.21, p<0.05)$ が有意であった。 ベース 表情ごとに 3 (挿入表情) $\times 2$ (変化速度) の 2 元配置の 分散分析（および Tukey-Kramer 法による多重比較） を行ったところ, ベース表情が怒りと悲しみの場合に, 怒りの挿入表情よりも笑顔の挿入表情に対して好意度が 有意に高くなっていた. しかし， ベースが笑顔の場合に は, 扦入表情の効果は見られず, 変化速度が速い場合に 好意度が高くなっていた。

次に, 挿入表情の分類判断に対する正答数 (Figure 7 および Figure 8 参照) について, ベースの表情, 途 中で変化する表情, 挿入表情の变化速度の 3 つを要因 とした 3 元配置の分散分析を行ったところ, 挿入表情 の主効果 $(F(2,595)=32.70, \quad p<0.001)$ が有意であり, ベース表情と挿入表情の交互作用 $(F(4,595)=3.67$, $p<0.01)$ および挿入表情と変化速度の交互作用 $(F(2,595)=3.13, p<0.05)$ が有意であった. ベース表 情ごとに 3 (挿入表情) $\times 2$ (变化速度) の 2 元配置の分散
分析（および Tukey-Kramer 法による多重比較）を 行ったところ, ベース表情が怒りと笑顔の場合に, 悲し みの挿入表情に対する分類成績が他の 2 つの挿入表情 に対する分類成績よりも悪かった。 また, ベース表情が 悲しみの場合は, 挿入表情と変化速度に交互作用が認め られた。 これは, 变化速度が遅い場合には, 悲しみの挿 入表情に対する分類成績が他の 2 つの挿入表情に対す る分類成績よりも悪かったが，变化速度が速い場合には， 3つの挿入表情の間に有意な差が認められなかったから である，正答率を見る限り，変化速度が速い場合に有意 差がなくなった原因は, 悲しみの正答率が高くなったか らであると思われるが，これは挿入表情をより正確に認 知できたからというよりは, むしろ表情認知がさらに困 難になり, ベースの表情（すなわち, 悲しみ）に分類判 断が大きく影響されたからではないかと考えられる.

実験 2 では, 表情の变化速度をさらに速めてみたが, 変化速度が 200 ミリ秒の条件における結果は全体的に 実験 1 とほぼ同様のあのが得られたといえる。挿入表 情が悲しみの場合には実験 1 と同じく困難さが見られ るが, 怒りと笑顔に関する限り, 被験者は挿入表情と整 合性のある好意度評定をしており, 表情分類課題におい てもチャンスレベルを超える正答率を得ていた.

しかし, 変化速度が速い条件 (130ミリ秒) では, 悲 しみに加えて怒りの挿入表情に対する処理む困難になっ てきている，表情分類の正答率が全体的に低下していて， 好意度評定においても, ベース表情が笑顔の場合には ベース表情が大きく影響されていることが見てとれる. 実際に, 怒りの挿入表情に対する分類成績を 3 (ベース 表情) $\times 2$ (变化速度)の 2 元配置の分散分析で分析して みると, 变化速度の主効果 $(F(1,175)=7.51, p<0.01)$ が有意であった．同様の分析を笑顔の挿入表情に対する 分類成績についても行ったが，笑顔の場合には变化速度 の違いによる分類成績の低下は見られなかった $(F<1)$. 悲しみの挿入表情が今回の実験におけるもっとも遅い变 化速度 (530 ミリ秒) においても処理の困難さを示して いるのに対して, 怒りの挿入表情は呈示時間が 200 ミ リ秒から 130 ミリ秒に減少したことによる影響を受け ているあのと考えられる.

\section{全体的考察}

本研究の主な目的は, 瞬間的な表情変化を人がどの程 度正確に認知できるか, あるいは, 表情認知は十分では なくても, 瞬間的な表情変化に対して情動的な反応を示 すかを検証することであった，表情变化の時間を 530 ミリ秒, 330 ミリ秒, 200 ミリ秒, 130 ミリ秒へと減少 させたが，少なくとも 200 ミリ秒までは，挿入表情が 怒りと笑顔の場合には, 表情認知および情動的反応のい ずれにおいても, 挿入表情そのものが情動的・認知的に 


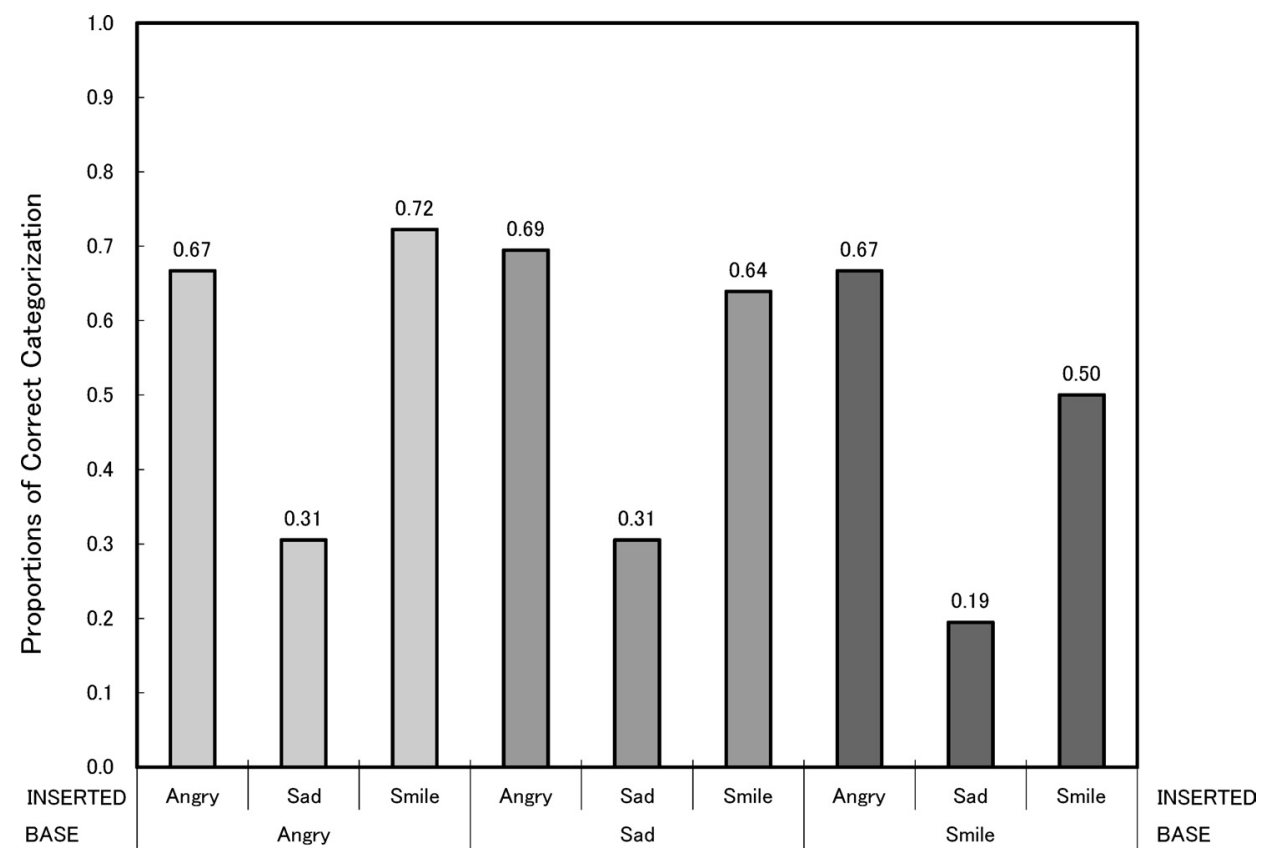

Figure 7. Proportions of correct categorization of inserted facial expressions as a function of base expressions for the $200 \mathrm{msec}$ condition in Experiment 2.

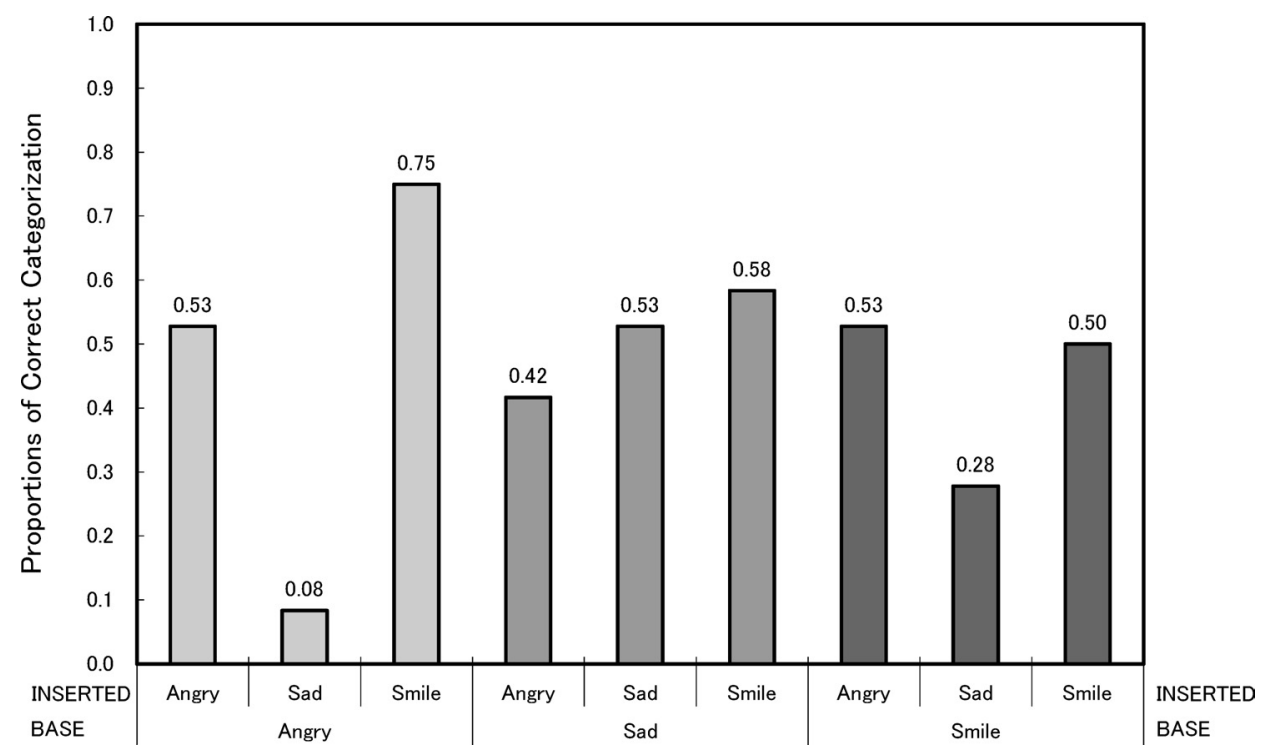

Figure 8. Proportions of correct categorization of inserted facial expressions as a function of base expressions for the $130 \mathrm{msec}$ condition in Experiment 2.

判断され処理されていることを示す結果が得られた。一 方，挿入表情が悲しみの場合は，挿入表情の情動的効果 および表情分類において，ベースの表情に依存する傾向 が見られた．特に，表情分類においてはチャンスレベル
程度の成績しか残せないケース屯みられ，全般的に分類 課題の成績は振るわなかった。

悲しみの表情分類の正答率が全般的に低く, 特にベー スの表情が怒りである場合に正答率が著しく低かったの 
は, 実験 1 の考察であ述べた通り, 悲しみという表情 が覚醒度の低い表情であるため, 怒りという覚醒度の高 い不快情動を表す表情が前後にくると悲しみの表情の効 果が抑制され, 他の表情, 特に見ていないはずの無表情 と混同されやすくなるからではないかと考えられる。こ のことは, 実験 1 の挿入表情の強度の弱い条件におけ る好意度評定の結果からも推測される. すなわち, ベー スの表情が怒りである場合に, 悲しみの挿入表情は無表 情と誤って認知されることが多く, そのため, 不快情動 を表す表情であるにもかかわらず好意度の低下が抑制さ れ, 結果的に, 他のベース表情のときには見られた笑顔 との有意差が現れなかったのではないかと考えられる.

情動を表す表情の中でも知覚処理の精度が優れている のは, 快情動よりあ不快情動であるとされ, 自分に向か う脅威信号は察知されやすいとされている（佐藤・吉 川，1999）。そうした脅威信号であるとされる怒りの表 情は他の表情に比べて認知されやすいと期待される. 本 研究では, 变化速度が 130 ミリ秒の場合を除いて, 怒 りの挿入表情に対する分類成績は笑顔の扦入表情に対す る分類成績とほぼ同等であった。しかし, 変化速度が 200 ミリ秒から 130 ミリ秒に上昇すると, 笑顔の分類 成績がはほとんど影響を受けなかったのに対して，怒り の分類成績は有意に低下してしまった。これについては, 快情動の表情が笑顔だけであるのに対して, 不快情動の 表情には怒りと悲しみの 2 つの選択肢があり, 速い呈 示時間では混乱しやすくなったという可能性が考えられ る.しかし，実験 2 の表情分類課題における反応混同 表を見る限り, 変化速度が 200 ミリ秒から 130 ミリ秒 に上昇したことの影響は, 悲しみへの分類への増加とい うよりは無表情や笑顔への分類の増加という形で現れて いる. 130 ミリ秒というきわめて短い呈示時間の中でも 与えられる笑顔の視覚的手がかりと，130ミリ秒では十 分に呈示できない怒りの視覚的手がかりとの違いが何で あるのかについて, それが今回用いた表情の動画像の特 徵に起因するあのなのか, あるいは 2 つの表情のより 一般的な特徵に基づくあのなのかについて今後検討を加 える必要がある。

\section{引用文献}

Bruce, V., \& Young, A. 1986 Understanding face recognition. British Journal of Psychology, 77, 305-327.

Charlesworth, W. R., \& Kreutzer, M. A. 1973 Facial expressions of infants and children. In P. Ekman (Ed.), Darwin and facial expression: A century of research in review. New York: Academic Press. Pp. 91-168.

Dion, K. 1972 Physical attractiveness and eva- luation of children's transgressions. Journal of Personality and Social Psychology, 24, 207-213.

Ekman, P. 1993 Facial Expression and Emotion. American Psychologist, 48, 376-379.

Ekman, P. 1994 Strong evidence for universals in facial expressions: A reply to Russell's mistaken critique. Psychological Bulletin, 115, 268-287.

Ekman, P., \& Friesen, W. V. 1978 Facial action coding system. Palo Alto, CA: Consulting Psychologists Press.

Kamachi, M., Bruce, V., Mukaida, S., Gyoba, J., Yoshikawa, S., \& Akamatsu, S. 2001 Dynamic properties influence the perception of facial expressions. Perception, 30, 875-887.

蒲池みゆき・行場次朗 1998 順応顔刺激の持続的 注視による表情認知の遅延 心理学研究, 69 , 97-104.

(Kamachi, M., \& Gyoba, J. 1998 Delays in recognizing facial expressions resulting from prolonged viewing of adaptation face stimuli. The Japanese Journal of Psychology, 69, 97-104.)

加藤 隆・赤松 茂 1998 顔の表情認知のマルチ モーダル特性について 電子情報通信学会技術 報告, HIP98-24, 17-22.

(Kato, T., \& Akamatsu, S. 1998 Multimodal characteristics of facial-expression judgment. Technical Report of the Institute of Electronics, Information and Communication Engineers, HIP98-24, 17-22.)

加藤 隆・中口 稔・木幡誠治・丸谷真美 1998 表情判断における顔の部位の役割 計測自動制 御学会 第 14 回ヒューマン・インタフェー ス・シンポジゥム論文集, 71-76.

(Kato, T., Nakaguchi, M., Kowata, S., \& Maruya, M. 1998 The role of facial part in facial-expression judgment. Proceedings of the Fourteenth Symposium on Human Interface, 71-76.)

桐田隆博 1993 表情を理解する 吉川左紀子・益 谷真・中村 真編 顔之心一顔の心理学入門一 第 9 章 サイエンス社 Pp. 197-221.

(Kirita, T.)

Klatzky, R. L. 1986 Levels of representation and memory for faces. In H. D. Ellis, M. A. Jeeves FRSE, F. Newcombe, \& A. Young 
(Eds.), Aspects of face processing. Dordrecht, The Netherlands: Martinus Nijhoff Publishers. Pp. 147-153.

McKelvie, S. J. 1973 The meaningfulness and meaning of schematic faces. Perception \& Psychophysics, 14, 343-348.

向田 茂・蒲池みゆき・尾田政臣・加藤 隆・吉 川左紀子・赤松 茂・千原國宏 2002 操作性を 考慮した顔画像合成システム：FUTON一顔認 知研究ッールとしての評価一電子情報通信学会 論文誌 (A), J85-A, 10 1126-1137.

(Mukaida, S., Kamachi, M., Oda, M., Kato, T., Yoshikawa, S., Akamatsu, S., \& Chihara, K. 2002 Facial image synthesis system: FUTON-Evaluation as tools for cognitive research on face processing-. The Transactions of the Institute of Electronics, Information and Communication Engineers $(A)$, J85-A, 10, 1126-1137.)

小川徳子・尾田政臣 1998 表情画像データベース の構築と基本特性評価 ATR Technical Report, TR-H-244, ATR 人間情報通信研究所. (Ogawa, T., \& Oda, M. 1998 Construction and evaluation of the facial expression database. ATR Technical Report, TR-H-244, ATR Human Information Processing Research Laboratories. )

Russell, J.A. 1997 Reading emotions from and into faces: Resurrecting a dimensionalcontextual perspective. In J. A. Russell, \& J.
M. Fernandez-Dols (Eds.), The psychology of facial expression. Cambridge, Cambridge University Press. Pp. 295-320.

Russell, J. A., \& Bullock, M. 1985 Multidimensional scaling of emotional facial expressions: Similarity from preschoolers to adults. Journal of Personality and Social Psychology, 48, 1290-1298.

Russell, J. A., \& Fehr, B. 1987 Relativity in the perception of emotion in facial expressions. Journal of Experimental Psychology: General, 116, 223-237.

佐藤 弥・吉川左紀子 1999 情動的表情による顔 知覚促進効果 電子情報通信学会技術報告, HCS99-26, 19-26.

(Sato, W., \& Yoshikawa, S. 1999 Enhancement effect of emotional expressions on perception of the faces. Technical Report of the Institute of Electronics, Information and Communication Engineers, HCS99-26, 19-26.)

Shepherd, J. W. 1989 The face and social attribution. In A. W. Young, \& H. D. Ellis (Eds.), Handbook of research on face processing. Amsterdam: North-Holland. Pp. 289-320.

Smith, C. A., \& Ellsworth, P. C. 1985 Patterns of cognitive appraisal in emotion. Journal of Personality and Social Psychology, 48, 813-838.

(2004 年 8 月 31 日受稿, 2005 年 2 月 11 日受理) 